\title{
REVIEW
}

\section{Quinagolide - a valuable treatment option for hyperprolactinaemia}

Anne Barlier and Philippe Jaquet

Interactions Cellulaires Neuroendocriniennes, Unite Mixte de Recherche 6544, Centre National de la Recherche Scientifique, Universite de la Mediterranee, Faculte de Medecine Nord, Bd Pierre Dramard, 13916 Marseille Cedex 20, France

(Correspondence should be addressed to P Jaquet; Email: jaquet.p@jean-roche.univ-mrs.fr)

\begin{abstract}
Hyperprolactinaemia is characterised by gonadal dysfunction, including infertility and reduced libido and, if left untreated, is associated with an increased risk of long-term complications, such as osteoporosis. The first-line therapy for patients with hyperprolactinaemia is pharmacological intervention with a dopamine agonist. Currently, there are three dopamine agonists available for hyperprolactinaemia therapy: bromocriptine, quinagolide and cabergoline. Bromocriptine has a long history of use; however, a range of $5-18 \%$ of patients are reported to show bromocriptine resistance, with only partial lowering of plasma prolactin levels and an absence of tumour shrinkage. The newer dopamine agonists, quinagolide and cabergoline, offer improved efficacy over bromocriptine, with a lower incidence of adverse events. Quinagolide and cabergoline have also demonstrated efficacy in many patients intolerant or resistant to bromocriptine. Thus, the selection of dopamine agonists available provides more than one option for pharmacological intervention of hyperprolactinaemia. This review discusses the clinical use of quinagolide in comparison to other dopamine agonists for hyperprolactinaemia therapy. Quinagolide may improve patient compliance to treatment owing to its reduced side effect profile, simple and rapid titration over just 7 days, once-daily dosing regimen and easy to use starter pack (available in some countries). Quinagolide offers an additional benefit for patients wishing to become pregnant, as it can be used until the point of confirmation of pregnancy. Therefore, as a well tolerated and effective therapy, with a simple dosing regimen, quinagolide should be considered as a first-line therapy in the treatment of hyperprolactinaemia.
\end{abstract}

European Journal of Endocrinology 154 187-195

\section{Introduction}

Elevated prolactin levels can result from physiological causes, such as pregnancy and stress, and pharmacological causes, including the use of neuroleptics, oestrogens, opiates, antihypertensive drugs, or calcium channel blockers (see (1)). Once physiological and iatrogenic stimuli have been eliminated as causes of elevated prolactin levels, the presence of a micro- or macroprolactinoma is the most likely cause of persistent pathological hyperprolactinaemia (2). These pituitary tumours increase prolactin levels via excessive prolactin production and by attenuation of the normal dopamine inhibition of prolactin secretion through possible disruption of the dopamine delivery pathway from the hypothalamus to the pituitary.

Symptoms of hyperprolactinaemia include signs of gonadal dysfunction, and female patients frequently present with oligomenorrhoea, amenorrhoea and galactorrhoea (3). Pathological hyperprolactinaemia is also associated with infertility (3) and reduced libido (4) and an increased risk of long-term complications including osteopoenia and osteoporosis (5-7). These long-term complications associated with elevated prolactin levels suggest that even patients who are unconcerned by their clinical symptoms or who do not wish to receive therapy in order to restore fertility should be considered for long-term therapeutic intervention.

Pharmacological intervention with dopamine agonists is considered the first-line therapy for patients with prolactinomas, reserving surgery or radiotherapy for patients who demonstrate resistance or intolerance to dopamine agonist therapy. Mimicking the action of dopamine, dopamine agonists, including bromocriptine, quinagolide and cabergoline are able to lower prolactin levels, decrease prolactinoma size and restore ovarian function (see (8)).

Initially, bromocriptine was considered the gold standard for dopamine agonist therapy; however, bromocriptine is associated with a range of side effects, 
leaving some patients intolerant to treatment. Bromocriptine administration via the vaginal route may reduce the incidence of side effects and offer an alternative to oral bromocriptine $(9,10)$. A range of $5-18 \%$ of patients have also been reported as resistant to bromocriptine treatment, with only partial lowering of plasma prolactin levels and an absence of tumour shrinkage (11-13) even after administration of high doses of bromocriptine. The newer drugs, quinagolide and cabergoline offer more effective and better tolerated treatment options compared with bromocriptine $(14,15)$. These more effective dopamine agonists have also shown efficacy in patients resistant or intolerant to bromocriptine $(11,16-24)$. Thus, the actual selection of dopamine agonists available provides more than one option for pharmacological intervention of hyperprolactinaemia, allowing patients who show resistance or intolerance to one dopamine agonist, such as bromocriptine, to be treated effectively with another, such as quinagolide $(11,16-22)$. This review discusses the clinical use of quinagolide in comparison to other dopamine agonists as a therapy option for hyperprolactinaemia.

\section{Quinagolide pharmacology}

\section{Quinagolide is selective for D2-type dopamine receptors}

Quinagolide (Norprolac, Ferring Pharmaceuticals, Lausanne, Switzerland) is a non-ergot derived dopamine agonist with a chemical structure similar to apomorphine (Fig. 1). Binding of quinagolide or other dopamine agonists to D2 dopamine receptors on the surface of lactotroph cells in the anterior pituitary reduces adenylyl cyclase activity, reduces intracellular cyclic adenosine monophosphate and inhibits prolactin secretion (25). Quinagolide acts specifically and with high affinity on D2-type dopamine receptors and has little affinity, at supra-pharmacological concentrations, for D1-type dopamine receptors (26). Cabergoline is an ergot-derived dopamine agonist, which also demonstrates low affinity for D1-type dopamine receptors and high affinity for D2-type receptors (27). In contrast, the ergot derivative bromocriptine is not a specific D2-type dopamine receptor agonist and can act as an antagonist at D1-type receptors (28).

Both the specificity and the non-ergot nature of quinagolide reduce the risk of side effects, such as nausea and peripheral vasospasm, compared with the lessspecific and ergot derivative dopamine agonists, such as bromocriptine $(29,30)$.

\section{Once-daily dosing of quinagolide}

The 22-hour half-life and 24-hour duration of action of quinagolide permit once-daily dosing; the potent prolactin-lowering effect of once-daily quinagolide has
A

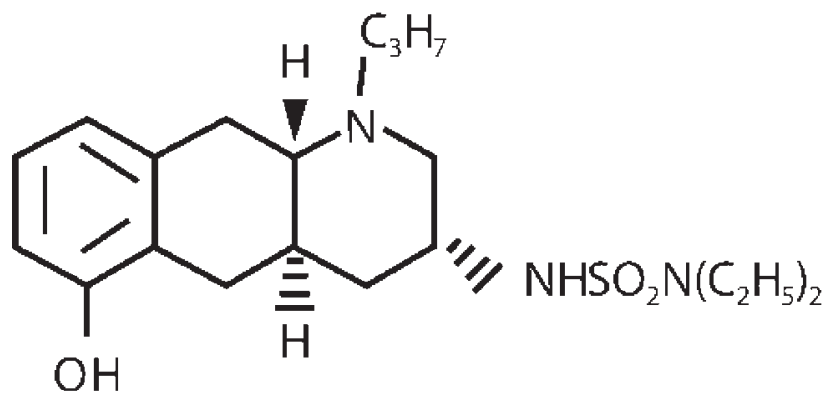

B<smiles>C=CCN1C[C@H](C(=O)N(CCCN(C)C)C(=O)NCC)CC2c3cccc4[nH]cc(c34)C[C@H]21</smiles>

C<smiles>CC(C)C[C@@H](O)[C@]12CCCN1C(=O)C[C@@](NC(=O)C1C=C3c4cccc5[nH]c(Br)c(c45)C[C@H]3N(C)C1)(C(C)C)O2</smiles>

Figure 1 The chemical structures of $(A)$ quinagolide, $(B)$ cabergoline and $(\mathrm{C})$ bromocriptine. 
been demonstrated in pharmacological and doseranging studies in both healthy volunteers (31) and patients with hyperprolactinaemia (32). Cabergoline is also a long-lasting therapy, with a half-life of 65 hour and a duration of action of 7-14 days, which is typically administered once or twice per week $(8,27)$. In comparison, the half-life of bromocrip-

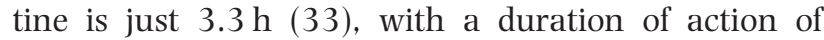
8-12 hours, necessitating multiple daily dosing. The once-daily dosing of quinagolide offers the potential to improve treatment success, in comparison to the conventional multiple-daily dosing with bromocriptine; studies with various pharmacological agents have shown that frequent dosing schedules can reduce patient compliance (34-37). The efficacy of a single evening dose of bromocriptine has been investigated and was shown in one study to provide equivalent control of prolactin levels with a reduced incidence and intensity of side effects compared with a conventional three-times-daily regimen (38).

\section{Initiation of quinagolide therapy}

\section{Maintenance dose options and 7-day titration of quinagolide}

Quinagolide is available in tablets of 0.025, 0.050, 0.075 and $0.150 \mathrm{mg}$ and is typically taken at a dose of $0.075 \mathrm{mg}$ once daily (32). Patients should be initiated onto quinagolide therapy at a dose of $0.025 \mathrm{mg}$ per day and increased to a dose of $0.075 \mathrm{mg}$ per day with a quick and simple titration over just 7 days. In this titration (available as a starter pack in some countries), patients receive $0.025 \mathrm{mg}$ per day for the first 3 days, followed by $0.050 \mathrm{mg}$ per day for the next 3 days (32). At Day 7, the dose is increased to $0.075 \mathrm{mg}$ per day and is maintained for at least 1 month until an evaluation of clinical effects and prolactin measurements is performed. If necessary, the quinagolide dose can be increased, in stepwise increments, until the dose achieving the optimal patient response is attained, up to a maximum dose of $0.3-0.6 \mathrm{mg}$ per day.

Cabergoline is typically initiated at a dose of $0.25-0.50 \mathrm{mg}$ on a twice-weekly basis. The dose is then adjusted after at least 1 month, according to the serum prolactin levels. The therapeutic dosage is usually $1 \mathrm{mg}$ per week and ranges from 0.25$10.5 \mathrm{mg}$ per week, typically administered in divided doses twice weekly (39). Bromocriptine is initiated at $1.25-2.50 \mathrm{mg}$ in divided doses administered twice a day. The majority of patients with hyperprolactinaemia respond to bromocriptine in divided doses of $7.5 \mathrm{mg}$ daily, but doses of up to $30 \mathrm{mg}$ per day have been used (11). Compared with bromocriptine, the simple titration of quinagolide, at the initiation of treatment, offers the opportunity to improve tolerability and patient compliance.

\section{Clinical experience with quinagolide}

\section{Efficacy in reduction of prolactin levels and prolactinoma size}

Once-daily quinagolide therapy in women with hyperprolactinaemia has been shown to effectively reduce prolactin levels and prolactinoma size and to relieve the associated symptoms, with particular respect to restoration of gonadal function and fertility $(11,15-21,30$, $32,40-47$ ) (Table 1). For example, treatment of 41 women with hyperprolactinaemia for 12-52 weeks with quinagolide reduced prolactin levels and resolved menstrual cycle irregularities in the majority of patients; amenorrhoea was resolved in 19 of the 25 women with this condition at week 12, and in 24 women at the end of the study. During this study, the prolactin levels were normalised in $71 \%$ of patients at a quinagolide dose of $\leq 0.1 \mathrm{mg}$ per day. However, further dose increases of up to $0.5 \mathrm{mg}$ per day following the 12-month study period resulted in normal prolactin levels in $95 \%$ of the patients (42). Another study evaluated the outcome of 40 patients with hyperprolactinaemia under quinagolide for 2-72 months. Of these 40 patients, 11 had microadenomas and 12 had macroadenomas. Quinagolide treatment reduced prolactin levels in all patients, where normalisation of prolactin levels was observed in $82 \%$ of the patients with no observable tumour at baseline, $73 \%$ of patients with microadenomas and $67 \%$ of patients with macroadenomas (18).

While elevated prolactin levels are encountered mostly in young females, men can also suffer from hyperprolactinaemia, typically leading to hypogonadism and symptoms including decreased libido, erectile dysfunction and abnormal semen analysis. In a study of the effects of chronic quinagolide treatment on sexual and gonadal function in male patients with hyperprolactinaemia, 14 men (13 with macroprolactinoma; one with microprolactinoma) were treated with quinagolide for 6-24 months (4). Analysis of the semen of these patients at baseline revealed reduced sperm count and motility, abnormal sperm morphology and decreased viability. Treatment with quinagolide effectively reduced the prolactin levels, with normalisation observed within 3 months in 13 of the 14 men. Analysis of the semen after 1 year of quinagolide treatment revealed increases in sperm number (from $5600 \pm 111 \mathrm{~mm}^{3}$ to $20564 \pm 587 \mathrm{~mm}^{3}$ ), motility at $1 \mathrm{~h}$ (from $24.8 \pm 0.1 \%$ to $52.6 \pm 0.5 \%$ ) and normal morphology (from $53.8 \pm 2.5 \%$ to $62.2 \pm 2.4 \%$ ). In addition, tumour mass was reduced by at least $30 \%$ in 8 of the 13 men with a macroprolactinoma. The authors concluded that normalisation of prolactin levels with quinagolide improves gonadal and sexual function and fertility in male patients with hyperprolactinaemia resulting from a prolactinoma (4). In a prospective, unblinded, multicenter trial, 26 patients with macroadenomas received once-daily quinagolide for 24 weeks 
Table 1 Summary of a series of studies investigating the use of quinagolide.

\begin{tabular}{|c|c|c|c|c|c|c|c|c|}
\hline & \multirow[b]{2}{*}{ Ref } & \multirow[b]{2}{*}{$\begin{array}{l}\text { No. of } \\
\text { patients }\end{array}$} & \multirow[b]{2}{*}{ Duration } & \multicolumn{5}{|c|}{ Outcomes at the end of the study } \\
\hline & & & & $\begin{array}{l}\text { Normalisation of PRL } \\
\text { levels (\% of patients) }\end{array}$ & $\begin{array}{l}\text { Prolactinoma size } \\
\text { (\% of cases) }\end{array}$ & $\begin{array}{l}\text { Regular menstrual } \\
\text { cycles (\% of patients) }\end{array}$ & Fertility & Galactorrhoea \\
\hline \multirow[t]{4}{*}{$\begin{array}{l}\text { Efficacy of } \\
\text { quinagolide }\end{array}$} & {$[42]$} & 41 & $\begin{array}{l}12-52 \\
\text { weeks }\end{array}$ & $\begin{array}{l}71 \% \text { with a once-daily } \\
\text { dose } \leq 0.1 \mathrm{mg}\end{array}$ & - & 96 & $\begin{array}{l}\text { Pregnancies occurred } \\
\text { within } 12 \text { months in } 4 / 11 \\
(36 \%) \text { infertile W }\end{array}$ & Resolved in $92 \%$ \\
\hline & [18] & 40 & $\begin{array}{l}2-72 \\
\text { months }\end{array}$ & $\begin{array}{l}\text { No tumour: } 82 \% \\
\text { Micro: } 73 \% \\
\text { Macro: } 67 \%\end{array}$ & $\begin{array}{l}\text { Micro: reduced in } 55 \% \\
\text { Macro: reduced in } 75 \%\end{array}$ & - & - & - \\
\hline & [4] & $\begin{array}{c}14 \\
\text { (male) }\end{array}$ & $\begin{array}{l}6-24 \\
\text { weeks }\end{array}$ & $93 \%$ & $\begin{array}{l}\text { Reduced by } \geq 30 \% \\
\text { in } 62 \% \text { of macro }\end{array}$ & - & $\begin{array}{l}\text { Increase sperm number, } \\
\text { motility at } 1 \text { hour, and } \\
\text { normal morphology }\end{array}$ & - \\
\hline & {$[48]$} & 26 & 24 weeks & $58 \%$ & Macro: reduced in $81 \%$ & 73 & $\begin{array}{l}\text { Sexual function improved } \\
\text { in } 71 \% \text { of affected males }\end{array}$ & - \\
\hline \multirow{2}{*}{$\begin{array}{l}\text { Quinagolide vs } \\
\text { bromocriptine }\end{array}$} & {$[40]$} & 45 & 24 weeks & 81 vs $70 \%$ & - & Restored with both drugs & Restored with both drugs & Reduced \\
\hline & {$[15]$} & 22 & 6 months & 91 vs $43 \%$ & - & In 91 vs 82 & $\begin{array}{l}67 \text { vs } 25 \% \text { of patients who } \\
\text { wanted to become pregnant } \\
\text { did so }\end{array}$ & - \\
\hline \multirow[t]{3}{*}{$\begin{array}{l}\text { Quinagolide in } \\
\text { bromocriptine- } \\
\text { resistant patients }\end{array}$} & {$[11]$} & 28 & 1 year & $43 \%$ & - & $\ln 40$ & $\begin{array}{l}\text { Nine pregnancies in seven } \\
\text { women within } 1.8 \pm 0.5 \text { years; } \\
\text { libido and potency improved } \\
\text { in men }\end{array}$ & - \\
\hline & [30] & 24 & 24 weeks & $67 \%$ & - & $\begin{array}{l}(94 \%) \text { patients with normalised } \\
\text { PRL levels }\end{array}$ & $\begin{array}{l}(94 \%) \text { patients with normalised } \\
\text { PRL levels }\end{array}$ & - \\
\hline & [43] & 20 & $\begin{array}{l}3-20 \\
\text { months }\end{array}$ & $70 \%$ & - & 70 & $\begin{array}{l}57 \% \text { of patients complaining } \\
\text { of infertility became pregnant }\end{array}$ & Resolved in $71 \%$ \\
\hline \multirow[t]{2}{*}{$\begin{array}{l}\text { Quinagolide vs } \\
\text { cabergoline }\end{array}$} & {$[51]$} & 20 & 12 weeks & 75 vs $90 \%(P<0.05)$ & - & $\begin{array}{l}\text { Similar efficacy } \\
\text { between drugs }\end{array}$ & $\begin{array}{l}\text { Similar efficacy } \\
\text { between drugs }\end{array}$ & $\begin{array}{l}\text { Similar efficacy } \\
\text { between drugs }\end{array}$ \\
\hline & {$[21]$} & 39 & 12 months & $\begin{array}{l}\text { Micro: } 100 \text { vs } 96 \% \\
\text { Macro: } 88 \text { vs } 88 \%\end{array}$ & $\begin{array}{l}\text { Micro: reduced by }>80 \% \\
\text { in } 22 \text { vs } 30 \% \\
\text { Macro: reduced by } 25 \text { vs } 31 \%\end{array}$ & - & - & - \\
\hline
\end{tabular}

Macro, macroadenoma; micro, microadenoma; PRL, prolactin; W, women. 
(48). Macroadenoma size decreased in 21 patients, regular menses were restored in 11 of 15 premenopausal women and sexual function improved in five of seven affected males (48).

Thus, together, these studies suggest that quinagolide is an effective therapy for the treatment of both male and female patients with hyperprolactinaemia and is able to alleviate the symptoms associated with elevated prolactin levels and to produce significant tumour shrinkage after 6-12 months of treatment in at least $61-80 \%$ of cases.

\section{Efficacy of quinagolide compared with bromocriptine}

Quinagolide has been shown to be at least as effective as bromocriptine in the treatment of hyperprolactinaemia. For example, one double-blind, randomized study of 47 women with long-standing hyperprolactinaemia compared once-daily quinagolide administration with twice-daily bromocriptine treatment (40). In this study, $81 \%$ of patients achieved normal prolactin levels after 24 weeks of quinagolide treatment compared with $70 \%$ of bromocriptine-treated patients. However, there was no significant difference between the treatment groups with respect to the prolactin levels at the end of the study. Both drugs were able to restore menses and fertility and reduce the incidence of galactorrhoea (40).

In another double-blind, randomized study that compared once-daily quinagolide with twice-daily bromocriptine, 22 women with hyperprolactinaemia were treated for 6 months (15). At the end of the study, the prolactin levels did not differ between treatment groups. However, prolactin levels returned to normal in 10 of the 11 patients in the quinagolide group, while in the bromocriptine group, four patients discontinued the study owing to side effects and normal prolactin levels were observed in three of the seven remaining patients. Regular menses were restored in 10 of the 11 women receiving quinagolide and nine of 11 patients receiving bromocriptine. While barrier contraception was recommended to patients in this study, two of the three women who wanted to conceive in the quinagolide group became pregnant within three ovulations as compared with one of four women in the bromocriptine group (15).

Quinagolide has also demonstrated efficacy in patients who are resistant to bromocriptine therapy $(11,16-21,30,40,43,49)$. Bromocriptine-resistance may be defined by the persistence of elevated prolactin levels and the absence of alleviation of clinical symptoms despite daily long-term administration of $15-30 \mathrm{mg}$ of bromocriptine (50). In a study of 28 patients with bromocriptine-resistant prolactinomas treated with quinagolide for $1-3$ years, restoration of normal prolactin levels and gonadal function occurred in 12 patients after 1 year of quinagolide treatment. During the 3 year follow-up period, nine pregnancies were observed in seven women (11). A double-blind, randomized study in 24 female patients with hyperprolactinaemia, 23 of whom were previously treated with bromocriptine, revealed a decrease in prolactin levels in all patients and normalisation of prolactin levels in 16 patients after 24 weeks. Regular menstruation and ovulation were restored in 15 of the 16 patients with normalised prolactin levels (30). These 15 patients received ongoing treatment with quinagolide for a total of 24 months. At 24 months, prolactin levels were normalised in all 15 patients, regular menses and ovulation were restored in 13 patients and galactorrhoea was relieved in 11 of the 14 patients presenting with galactorrhoea at baseline (30).

In another prospective trial, 20 women with persistent hyperprolactinaemia received quinagolide for 3-20 months (43). Prolactin levels decreased in all patients after 3 months of treatment, with an average decrease from baseline of $85 \%$ by the end of the study. Of the 20 women in this study, 19 had previously been treated with bromocriptine. Normal prolactin levels were restored in 13 patients after 3 months and in 14 patients at the end of the study, in accord with restoration of normal menses. Of the seven patients in this study complaining of infertility at baseline, four became pregnant and delivered healthy babies (43). A similar efficacy of quinagolide, in bromocriptine-resistant patients, was also reported in another smaller study (16).

Finally, treatment with once-daily quinagolide in 21 patients with prolactinomas resistant to bromocriptine was evaluated according to the prolactin levels at baseline (49). In the 10 patients with the highest prolactin levels at baseline $(948 \pm 538 \mu \mathrm{g} / \mathrm{l})$, prolactin levels decreased by $48 \%$ overall (49); however, no reduction in tumour size was observed. In the 11 patients with mean baseline prolactin levels of $468 \pm 160 \mu \mathrm{g} / \mathrm{l}$, normoprolactinaemia was obtained in all patients after $1-6$ months of treatment with quinagolide and tumour size decreased by at least $25 \%$ in 6 patients (49). Other studies have reported an improved tolerance with quinagolide in patients previously intolerant to bromocriptine (17). In a study in which quinagolide efficacy was investigated in 20 bromocriptine-intolerant patients, quinagolide reduced prolactin levels in patients with macroprolactinomas $(-91 \%)$ after 1 year of therapy. Decreases in tumour size were also observed $(-74 \%)$ and were correlated with the decrease in prolactin levels $(P<0.01)(17)$.

Thus, these studies demonstrate that quinagolide is able to improve prolactin levels and the associated clinical symptoms in patients who demonstrate resistance or intolerance to previous dopamine agonist therapy with bromocriptine. 


\section{Efficacy of quinagolide compared with cabergoline}

Several studies have investigated the efficacy of quinagolide and cabergoline in patients with hyperprolactinaemia $(21,51-53)$. In a randomized, cross-over study, 20 patients with hyperprolactinaemia received once-daily quinagolide or twice-weekly cabergoline for 12 weeks, with the two treatment phases separated by a wash-out period of 12 weeks with placebo (51). In this study, a higher percentage of patients with hyperprolactinaemia achieved normal prolactin levels with cabergoline compared with quinagolide (90 vs $75 \% ; P<0.05)$. However, clinical efficacy was similar between treatments in terms of improvement of symptoms, such as amenorrhoea, oligomenorrhoea, galactorrhoea and impotence, and there was no difference in the occurrence of side-effects (51).

Another study investigated the treatment of 39 patients with prolactinomas with once-daily quinagolide and twice-weekly cabergoline (21). Of the 39 patients, 23 patients had microprolactinomas and 16 had macroprolactinomas. Treatment with quinagolide for 12 months was followed by a 12-month wash-out period and then cabergoline treatment was given for a further 12-month period. The 12-month withdrawal of dopamine agonist therapy was introduced in this protocol in order to evaluate the recurrence of hyperprolactinaemia. After treatment with quinagolide for the first 12 months, prolactin levels normalised in $100 \%$ of patients with microprolactinomas and in $88 \%$ of patients with macroprolactinomas. Tumour volume, assessed by magnetic resonance imaging, was reduced by more than $80 \%$ in $22 \%$ of patients with microprolactinomas and $25 \%$ of patients with macroprolactinomas. At the end of the wash-out period, prolactin levels had increased in all patients, but were significantly lower than the prolactin levels measured at baseline before initiation of quinagolide therapy $(P=0.01)$. After 12 months of cabergoline treatment, prolactin levels normalised in $96 \%$ of patients with microprolactinoma and $88 \%$ with macroprolactinoma. Tumour volume reductions of more than $80 \%$ were noted in $30 \%$ and $31 \%$ of patients with micro- and macroprolactinomas, respectively. After 12 months of withdrawal from cabergoline treatment, recurrence of hyperprolactinaemia was observed in all patients with macroprolactinomas and 19 of the 23 patients with microprolactinomas. Therefore, in this study, quinagolide and cabergoline normalised prolactin levels in the majority of patients after 12 months of treatment, but recurrence of hyperprolactinaemia was observed in all patients with macroprolactinomas withdrawn from cabergoline and quinagolide (21). In another randomized cross-over study, 12 patients received either once-daily quinagolide $(0.075 \mathrm{mg})$ or twice-weekly cabergoline $(0.5 \mathrm{mg})$ for 12 weeks (53). Treatment with the second dopamine agonist was initiated after the recurrence of hyperprolactinaemia; nine patients completed both treatment cycles. In this study, the clinical effects were similar with both cabergoline and quinagolide and, interestingly, only one patient remained resistant to both dopamine agonists (53). In a study of 26 children or adolescents with prolactinomas, 16 were considered resistant or intolerant to bromocriptine (52). Quinagolide therapy allowed normalization of prolactin values in five of these 16 cases. Subsequent treatment with cabergoline allowed further prolactin normalisation in six of the remaining 10 cases (52). This study suggests that while some patients show resistance to dopamine agonist therapy, those resistant to one therapy may be treated effectively with another dopamine agonist; however a small proportion of patients still appear to be resistant to pharmacotherapy with bromocriptine, quinagolide and cabergoline.

\section{Safety \\ Tolerability}

As a non-ergot derivative, quinagolide is unlikely to cause side effects such as peripheral vasospasm, erythromelalgia, and pleuropulmonary or retroperitoneal fibrosis that occasionally occur with ergot derivatives, such as bromocriptine (29). The specificity of quinagolide for D2-type dopamine receptors is also likely to result in fewer side effects compared with dopamine agonists, such as bromocriptine that also act on D1type dopamine receptors.

Indeed, quinagolide has shown better tolerability compared with bromocriptine; in one double-blind, randomized 6-month study in 22 women with persistent hyperprolactinaemia, quinagolide was significantly better tolerated compared with bromocriptine $(P=0.025)(15)$. While cabergoline is able to act on D1-type dopamine receptors, it has only a low affinity for these receptors and demonstrates a high affinity for D2-type receptors (54). Cabergoline has also been used effectively to treat hyperprolactinaemia with a low incidence of side effects $(14,39,55-58)$. The better tolerability of cabergoline compared with bromocriptine (14) may be related not only to the high affinity for D2-type receptors, but also to the longer half-life of cabergoline, which results in fewer changes in drug concentration in the blood.

As mentioned above, quinagolide has also been used effectively and safely in patients demonstrating bromocriptine intolerance $(15,18,22)$; cabergoline has also shown efficacy in these patients $(39,57)$. In studies with quinagolide, the most frequently reported side effects tend to be nausea and headache, but with most reported as mild to moderate in intensity, often transient and occurring within the first few weeks of treatment $(15,30,40,42,43)$. Quinagolide has a good safety profile, with, for example, no reported 
changes in blood biochemistry, haematology, blood pressure or pulse rate $(15,30,40,43,48)$.

Thus, the newer and more specific dopamine agonists, quinagolide and cabergoline, offer safe and effective treatment options that are better tolerated than bromocriptine and show efficacy in bromocriptineintolerant patients. In some countries, these more specific dopamine D2 'superagonists' have replaced bromocriptine in the medical management of hyperprolactinaemia.

\section{Treatment during pregnancy}

Bromocriptine does not appear to be a teratogen during early pregnancy and is not associated with any detrimental effect on pregnancy or foetal development (59-63) or any increase in spontaneous abortions, ectopic or multiple pregnancies or preterm deliveries (59-61). However, it is recommended that patients with microprolactinomas suspend treatment with bromocriptine once pregnancy has been confirmed to avoid any potential harmful effects (64).

The 22-hour half life of quinagolide allows this dopamine agonist to be used until the point of confirmed pregnancy. This allows patients who wish to become pregnant to continue quinagolide therapy for hyperprolactinaemia whilst trying to conceive. It is generally recommended to withdraw dopamine agonist therapy during pregnancy in patients with prolactinomas. There are limited published data detailing quinagolide use during pregnancy; however, no teratogenic effects during early pregnancy have been reported $(11,15$, $18,40,42,43)$. In the author's personal experience, a normal outcome was observed in a series of 30 pregnancies. Indeed, a multicentre prospective analysis of the pregnancies outcome in women treated with quinagolide must be undertaken.

It is recommended that patients cease cabergoline use at least 1 month prior to trying to conceive owing to the long half-life of this agent. However, cabergoline has demonstrated a good safety record in the small number (approximately 300) of cases in which this dopamine agonist was taken during early pregnancy $(58,65)$ and there have been no reported teratogenic effects or an increase in the rate of spontaneous abortion $(57,58,65-67)$.

\section{Conclusion}

The importance of treating hyperprolactinaemia and the need for continual therapy must not be underestimated in order to resolve symptoms and prevent the development of long-term complications associated with elevated prolactin levels. Bromocriptine has been available for the treatment of hyperprolactinaemia for over 25 years and as such, this generic and inexpensive dopamine agonist is often chosen as the first-line therapy option. However, the newer and more selective dopamine agonists, quinagolide and cabergoline offer more effective and better tolerated treatment options for patients compared with bromocriptine. In addition, quinagolide may improve patient compliance to treatment owing to its reduced side effect profile, simple and rapid titration over just 7 days, once-daily dosing regimen and easy to use starter pack (available in some countries). Quinagolide offers an additional benefit for patients wishing to become pregnant, as it can be used until the point of confirmation of pregnancy. In summary, this well tolerated and effective therapy, with a simple dosing regimen should be considered as a first-line therapy in the treatment of hyperprolactinaemia.

\section{References}

1 Verhelst J \& Abs R. Hyperprolactinemia: pathophysiology and management. Treatments in Endocrinology 20032 23-32.

2 Mah PM \& Webster J. Hyperprolactinemia: etiology, diagnosis, and management. Seminars in Reproductive Medicine 200220 365-374.

3 Luciano AA. Clinical presentation of hyperprolactinemia. Journal of Reproductive Medicine 199944 1085-1090.

4 Colao A, De Rosa M, Sarnacchiaro F, Di Sarno A, Landi ML, Iervolino E, Zarrilli S, Merola B \& Lombardi G. Chronic treatment with CV 205-502 restores the gonadal function in hyperprolactinemic males. European Journal of Endocrinology 1996135 548-552.

5 Vartej P, Poiana C \& Vartej I. Effects of hyperprolactinemia on osteoporotic fracture risk in premenopausal women. Gynecological Endocrinology 200115 43-47.

6 Klibanski A, Neer RM, Beitins IZ, Ridgway EC, Zervas NT \& McArthur JW. Decreased bone density in hyperprolactinemic women. New England Journal of Medicine 1980303 1511-1514.

7 Klibanski A \& Greenspan SL. Increase in bone mass after treatment of hyperprolactinemic amenorrhea. New England Journal of Medicine $1986315542-546$.

8 Bankowski BJ \& Zacur HA. Dopamine agonist therapy for hyperprolactinemia. Clinical Obstetrics and Gynecology $2003 \mathbf{4 6}$ 349-362.

9 Kletzky OA \& Vermesh M. Effectiveness of vaginal bromocriptine in treating women with hyperprolactinemia. Fertility and Sterility $198951269-272$.

10 Ginsburg J, Hardiman P \& Thomas M. Vaginal bromocriptineclinical and biochemical effects. Gynecological Endocrinology $19926119-126$.

11 Morange I, Barlier A, Pellegrini I, Brue T, Enjalbert A \& Jaquet P. Prolactinomas resistant to bromocriptine: long-term efficacy of quinagolide and outcome of pregnancy. European Journal of Endocrinology $1996135413-420$.

12 Pellegrini I, Rasolonjanahary R, Gunz G, Bertrand P, Delivet S, Jedynak CP, Kordon C, Peillon F, Jaquet P \& Enjalbert A. Resistance to bromocriptine in prolactinomas. Journal of Clinical Endocrinology and Metabolism 198969 500-509.

13 Brue T, Pellegrini I, Priou A, Morange I \& Jaquet P. Prolactinomas and resistance to dopamine agonists. Hormone Research 199238 84-89.

14 Webster J, Piscitelli G, Polli A, Ferrari CI, Ismail I \& Scanlon MF. A comparison of cabergoline and bromocriptine in the treatment of hyperprolactinemic amenorrhea. Cabergoline Comparative Study Group. New England Journal of Medicine 1994331 904-909.

15 Homburg R, West C, Brownell J \& Jacobs HS. A double-blind study comparing a new non-ergot, long-acting dopamine agonist, 
CV 205-502, with bromocriptine in women with hyperprolactinaemia. Clinical Endocrinology (Oxford) 199032 565-571.

16 Glaser B, Nesher Y \& Barziliai S. Long-term treatment of bromocriptine-intolerant prolactinoma patients with CV 205-502. Journal of Reproductive Medicine $199439449-454$.

17 van der Lely AJ, Brownell J \& Lamberts SW. The efficacy and tolerability of CV 205-502 (a nonergot dopaminergic drug) in macroprolactinoma patients and in prolactinoma patients intolerant to bromocriptine. Journal of Clinical Endocrinology and Metabolism 199172 1136-1141.

18 Schultz PN, Ginsberg L, McCutcheon IE, Samaan N, Leavens M \& Gagel RF. Quinagolide in the management of prolactinoma. Pituitary $20003239-249$.

19 Rohmer V, Freneau E, Morange I \& Simonetta C. Efficacy of quinagolide in resistance to dopamine agonists: results of a multicenter study. Club de l'Hypophyse. Annals of Endocrinology (Paris) 2000 61 411-417.

20 Duranteau L, Chanson P, Lavoinne A, Horlait S, Lubetzki J \& Kuhn JM. Effect of the new dopaminergic agonist CV 205-502 on plasma prolactin levels and tumour size in bromocriptine-resistant prolactinomas. Clinical Endocrinology (Oxford) 199134 25-29.

21 Di Sarno A, Landi ML, Marzullo P, Di Somma C, Pivonello R, Cerbone G, Lombardi G \& Colao A. The effect of quinagolide and cabergoline, two selective dopamine receptor type 2 agonists, in the treatment of prolactinomas. Clinical Endocrinology (Oxford) 200053 53-60.

22 Merola B, Sarnacchiaro F, Colao A, Di Somma C, Di Sarno A, Ferone D, Selleri A, Landi ML, Schettini G, Nappi C et al. Positive response to compound CV 205-502 in hyperprolactinemic patients resistant to or intolerant of bromocriptine. Gynecological Endocrinology 19948 175-181.

23 Delgrange E, Maiter D \& Donckier J. Effects of the dopamine agonist cabergoline in patients with prolactinoma intolerant or resistant to bromocriptine. European Journal of Endocrinology 1996134 $454-456$

24 Colao A, Di Sarno A, Sarnacchiaro F, Ferone D, Di Renzo G, Merola B, Annunziato L \& Lombardi G. Prolactinomas resistant to standard dopamine agonists respond to chronic cabergoline treatment. Journal of Clinical Endocrinology and Metabolism 1997 $82876-883$.

25 McDonald WM, Sibley DR, Kilpatrick BF \& Caron MG. Dopaminergic inhibition of adenylate cyclase correlates with high affinity agonist binding to anterior pituitary D2 dopamine receptors. Molecular and Cellular Endocrinology 198436 201-209.

26 Closse A, Camps M, Wanner A \& Palacios JM. In vivo labeling of brain dopamine D2 receptors using the high-affinity specific D2 agonist (3H)CV 205-502. Brain Research $1988440123-132$.

27 Del Dotto P \& Bonuccelli U. Clinical pharmacokinetics of cabergoline. Clinical Pharmacokinetics 200342 633-645.

28 Factor SA. Dopamine agonists. Medical Clinics of North America 199983 415-443, vi-vii.

29 Brooks DJ. Dopamine agonists: their role in the treatment of Parkinson's disease. Journal of Neurology, Neurosurgery and Psychiatry 200068 685-689.

30 Rasmussen C, Brownell J \& Bergh T. Clinical response and prolactin concentration in hyperprolactinemic women during and after treatment for 24 months with the new dopamine agonist, CV 205-502. Acta Endocrinologica (Copenhagen) 1991125 170-176.

31 Gaillard RC, Abeywickrama K, Brownell J \& Muller AF. Specific effect of CV 205-502, a potent nonergot dopamine agonist, during a combined anterior pituitary function test. Journal of Clinical Endocrinology and Metabolism 198968 329-335.

32 Rasmussen C, Bergh T, Wide L \& Brownell J. CV 205-502: a new long-acting drug for inhibition of prolactin hypersecretion. Clinical Endocrinology (Oxford) 198726 321-326.

33 Thorner M, Flückiger E \& Calne D. Bromocriptine, a clinical and pharmacological review. New York: Raven Press, 1980.

34 Hawkins T. Impact of once- and twice-daily dosing regimens on adherence and overall safety. AIDS Reader $200414320-322$ $324,329-331,334-326$.
35 Moyle G. Once-daily therapy: less is more. International Journal of STD and AIDS $2003 \mathbf{1 4} 1-5$.

36 Greenberg RN. Overview of patient compliance with medication dosing: a literature review. Clinical Therapeutics 19846 592-599.

37 Claxton AJ, Cramer J \& Pierce C. A systematic review of the associations between dose regimens and medication compliance. Clinical Therapeutics $2001231296-1310$.

38 Ciccarelli E, Mazza E, Ghigo E, Guidoni F, Barberis A, Massara F \& Camanni F. Long term treatment with oral single administration of bromocriptine in patients with hyperprolactinemia. Journal of Endocrinological Investigation 198710 51-53.

39 Ferrari CI, Abs R, Bevan JS, Brabant G, Ciccarelli E, Motta T, Mucci M, Muratori M, Musatti L, Verbessem G \& Scanlon MF. Treatment of macroprolactinoma with cabergoline: a study of 85 patients. Clinical Endocrinology (Oxford) 199746 409-413.

40 van der Heijden PF, de Wit W, Brownell J, Schoemaker J \& Rolland R. CV 205-502, a new dopamine agonist, versus bromocriptine in the treatment of hyperprolactinaemia. European Journal of Obstetrics, Gynecology, and Reproductive Biology 199140 $111-118$.

41 van der Heijden PF, Rolland R, Thomas CM \& Brownell J. Endocrine effects of CV 205-502, a new dopamine agonist, in hyperprolactinemic women. Gynecological Endocrinology $1988 \quad 2$ $233-248$.

42 van der Heijden PF, Lappohn RE, Corbey RS, de Goeij WB, Brownell J \& Rolland R. The effectiveness, safety, and tolerability of CV 205-502 in hyperprolactinemic women: a 12-month study. Fertility and Sterility 198952 574-579.

43 Shoham Z, Homburg R \& Jacobs HS. CV 205-502-effectiveness, tolerability, and safety over 24-month study. Fertility and Sterility $199155501-506$.

44 Barnett PS, Palazidou E, Miell JP, Coskeran PB, Butler J, Dawson JM, Maccabe J \& McGregor AM. Endocrine function, psychiatric and clinical consequences in patients with macroprolactinomas after long-term treatment with the new non-ergot dopamine agonist CV205-502. Quarterly Journal of Medicine $199181891-906$.

45 Serri O, Beauregard H, Lesage J, Pedneault L, Comtois R, Jilwan N, Somma M, Vachon L \& Brownell J. Long term treatment with CV 205-502 in patients with prolactin-secreting pituitary macroadenomas. Journal of Clinical Endocrinology and Metabolism 199071 $682-687$.

46 Vance ML, Cragun JR, Reimnitz C, Chang RJ, Rashef E, Blackwell RE, Miller MM \& Molitch ME. CV 205-502 treatment of hyperprolactinemia. Journal of Clinical Endocrinology and Metabolism $198968336-339$.

47 Khalfallah Y, Claustrat B, Grochowicki M, Flocard F, Horlait S, Serusclat P \& Sassolas G. Effects of a new prolactin inhibitor, CV 205-502, in the treatment of human macroprolactinomas. Journal of Clinical Endocrinology and Metabolism $1990 \quad 71$ 354-359.

48 Vance ML, Lipper M, Klibanski A, Biller BM, Samaan NA \& Molitch ME. Treatment of prolactin-secreting pituitary macroadenomas with the long-acting non-ergot dopamine agonist CV 205502. Annals of Internal Medicine 1990112 668-673.

49 Brue T, Pellegrini I, Gunz G, Morange I, Dewailly D, Brownell J, Enjalbert A \& Jaquet P. Effects of the dopamine agonist CV 205502 in human prolactinomas resistant to bromocriptine. Journal of Clinical Endocrinology and Metabolism $1992 \mathbf{7 4}$ $577-584$.

50 Di Sarno A, Landi ML, Cappabianca P, Di Salle F, Rossi FW, Pivonello R, Di Somma C, Faggiano A, Lombardi G \& Colao A. Resistance to cabergoline as compared with bromocriptine in hyperprolactinemia: prevalence, clinical definition, and therapeutic strategy. Journal of Clinical Endocrinology and Metabolism $2001865256-5261$.

51 De Luis DA, Becerra A, Lahera M, Botella JI, Valero \& Varela C. A randomized cross-over study comparing cabergoline and quinagolide in the treatment of hyperprolactinemic patients. Journal of Endocrinological Investigation 200023 428-434. 
52 Colao A, Loche S, Cappa M, Di Sarno A, Landi ML, Sarnacchiaro F, Facciolli G \& Lombardi G. Prolactinomas in children and adolescents. Clinical presentation and long-term follow-up. Journal of Clinical Endocrinology and Metabolism $1998 \mathbf{8 3} 2777-2780$.

53 Giusti M, Porcella E, Carraro A, Cuttica M, Valenti S \& Giordano G. A cross-over study with the two novel dopaminergic drugs cabergoline and quinagolide in hyperprolactinemic patients. Journal of Endocrinological Investigation 199417 51-57.

54 Rains CP, Bryson HM \& Fitton A. Cabergoline. A review of its pharmacological properties and therapeutic potential in the treatment of hyperprolactinaemia and inhibition of lactation. Drugs $199549255-279$.

55 Biller BM, Molitch ME, Vance ML, Cannistraro KB, Davis KR, Simons JA, Schoenfelder JR \& Klibanski A. Treatment of prolactin-secreting macroadenomas with the once-weekly dopamine agonist cabergoline. Journal of Clinical Endocrinology and Metabolism $1996812338-2343$.

56 Colao A, Di Sarno A, Landi ML, Scavuzzo F, Cappabianca P, Pivonello R, Volpe R, Di Salle F, Cirillo S, Annunziato L \& Lombardi G. Macroprolactinoma shrinkage during cabergoline treatment is greater in naive patients than in patients pretreated with other dopamine agonists: a prospective study in 110 patients. Journal of Clinical Endocrinology and Metabolism 2000 $852247-2252$.

57 Ciccarelli E, Giusti M, Miola C, Potenzoni F, Sghedoni D, Camanni F \& Giordano G. Effectiveness and tolerability of long term treatment with cabergoline, a new long-lasting ergoline derivative, in hyperprolactinemic patients. Journal of Clinical Endocrinology and Metabolism 198969 725-728.

58 Verhelst J, Abs R, Maiter D, van den Bruel A, Vandeweghe M, Velkeniers B, Mockel J, Lamberigts G, Petrossians P, Coremans P, Mahler C, Stevenaert A, Verlooy J, Raftopoulos C \& Beckers A. Cabergoline in the treatment of hyperprolactinemia: a study in 455 patients. Journal of Clinical Endocrinology and Metabolism $1999842518-2522$.
59 Krupp P \& Monka C. Bromocriptine in pregnancy: safety aspects. Klinische Wochenschrift 198765 823-827.

60 Czeizel A, Kiss R, Racz K, Mohori K \& Glaz E. Case-control cytogenetic study in offspring of mothers treated with bromocriptine during early pregnancy. Mutation Research $198921023-27$.

61 Raymond JP, Goldstein E, Konopka P, Leleu MF, Merceron RE \& Loria Y. Follow-up of children born of bromocriptine-treated mothers. Hormone Research 198522 239-246.

62 Chiodini I \& Liuzzi A. PRL-secreting pituitary adenomas in pregnancy. Journal of Endocrinological Investigation 200326 96-99.

63 Webster J. A comparative review of the tolerability profiles of dopamine agonists in the treatment of hyperprolactinaemia and inhibition of lactation. Drug Safety $199614228-238$.

64 de Wit W, Coelingh Bennink HJ \& Gerards LJ. Prophylactic bromocriptine treatment during pregnancy in women with macroprolactinomas: report of 13 pregnancies. British Journal of Obstetrics and Gynaecology 198491 1059-1069.

65 Ciccarelli E, Grottoli S, Razzore P, Gaia D, Bertagna A, Cirillo S, Cammarota T, Camanni M \& Camanni F. Long-term treatment with cabergoline, a new long-lasting ergoline derivate, in idiopathic or tumorous hyperprolactinaemia and outcome of druginduced pregnancy. Journal of Endocrinological Investigation 1997 20 547-551.

66 Ricci E, Parazzini F, Motta T, Ferrari CI, Colao A, Clavenna A, Rocchi F, Gangi E, Paracchi S, Gasperi M, Lavezzari M, Nicolosi AE, Ferrero S, Landi ML, Beck-Peccoz P \& Bonati M. Pregnancy outcome after cabergoline treatment in early weeks of gestation. Reproductive Toxicology $200216791-793$.

67 Webster J. Clinical management of prolactinomas. Baillieres Best Practice and Research in Clinical and Endocrinological Metabolism 199913 395-408.

Received 8 September 2005

Accepted 18 October 2005 